\title{
AN INVESTIGATION INTO THE APPLICABILITY OF SUPER GRIDS IN A SUB-SAHARAN AFRICAN CONTEXT
}

\author{
M. Nel ${ }^{1 *} \&$ I.H. de Kock ${ }^{1}$
}

\section{ARTICLE INFO}

Article details

Presented at the $32^{\text {nd }}$ annual conference of the Southern African Institute for Industrial Engineering (SAIIE), held from 4-6 October 2021 in Muldersdrift, South Africa.

Available online $\quad 29$ Nov 2021

\section{Contact details}

Corresponding author 20773129@sun.ac.za

\section{Author affiliations}

1 Department of Industrial

Engineering, University of Stellenbosch, South Africa

\section{ORCID® identifiers}

M.Nel

https://orcid.org/0000-0003-3071-3020

\section{I.H. de Kock}

https://orcid.org/0000-0003-4136-7418

\section{DOI}

http://dx.doi.org/10.7166/32-3-2612
ABSTRACT

There is a need in energy-poor sub-Saharan Africa for a system to manage energy more efficiently and effectively both within and between countries. An approach that has been proven in other parts of the world to facilitate this is super grids. With their interconnection and information management systems, super grids can contribute to the increasingly effective and efficient management of energy, and they have the potential to increase sustainability. The applicability of such super grids in the sub-Saharan African context is still uncertain and is scientifically under-explored; thus there is a need to establish their applicability in a sub-Saharan African context. In this article, the literature on super grids is analysed and contextualised from a bibliometric and content analysis perspective, in order to draw parallels between such super grids and the sub-Saharan African context, and thus to investigate their applicability in that context.

\section{OPSOMMING}

Daar is 'n behoefte in energie-arm sub-Sahara Afrika vir'n stelsel om energie meer effektief en doeltreffend te bestuur binne en tussen lande. ' $n$ Benadering wat reeds in ander dele van die wêreld bewys is om die bestuur van energie meer effektief en doeltreffend te maak, is super energienetwerke. Met super energienetwerke se interkonneksies en inligtingbestuurstelsels kan dit bydra tot die verbetering van effektiewe en doeltreffende bestuur van energie, en het dit die potensiaal om volhoubaarheid te verhoog. Die toepaslikheid van sulke super energienetwerke in sub-Sahara Afrika is steeds onseker en word wetenskaplik onder-ontgin: daar is dus 'n behoefte om die toepaslikheid daarvan binne 'n sub- Sahara Afrika-konteks vas te stel. In hierdie artikel word die literatuur oor super energienetwerke ontleed en gekontekstualiseer vanuit in bibliometriese en inhoudontledingsperspektief, om ten einde parallelle tussen sulke super energienetwerke en die sub-Sahara Afrika konteks te trek; die toepaslikheid daarvan in daardie konteks word so ondersoek.

\section{INTRODUCTION}

In the 21st century, the energy consumption of countries is closely linked to their economic growth and development [1]. Sub-Saharan Africa has one of the lowest energy consumptions per capita in the world, but the demand for energy in Africa is predicted to increase by 600 per cent between 2010 and 2040 [2]. The severity of the problems flowing from shortages or disruptions in energy supply cannot be ignored, given the poverty and low economic growth in the individual countries of the sub-Saharan region. Although the region has a low energy consumption, it is blessed with a diverse range of energy resources that, if harnessed, should adequately serve the energy needs of all the countries in the region, and should even lead to a net energy supply.

An approach that has proved to increase energy accessibility significantly in some parts of the world is the super grid concept. A super grid is described as "large continent-wide expansions of existing and planned high voltage power grids which have been proposed for bulk power transfers across international boundaries and for enhanced stability of underlying power infrastructure". [3]. Given this definition of a super grid, it is evident that the sub-Saharan African region already fits one of the criteria of the scale of 
such a network, especially given its size of 9.4 million square miles. There are also 46 countries in the region where energy can be traded and, with the African Continental Free Trade Agreement that was concluded in 2018, the potential for energy trade has never been better.

Given how a super grid can solve sub-Saharan Africa's desperate demand for energy, and given that 32 of the 48 countries in the region already face an energy crisis [4], the need aggressively to seek a solution through systematic research has never been more important than now. This paper will investigate and analyse whether a super grid would be applicable to the sub-Saharan African context, based on the research and projects that have already been completed elsewhere in this specialised field of energy management. This paper will use bibliometric and content analysis perspectives to gather the correct literature, and then analyse it to investigate whether there are any parallels between the successful application of super grids elsewhere in the world and the sub-Saharan African context.

\section{METHODOLOGY}

In this section the methodologies followed for the bibliometric analysis and the content analysis are outlined. The bibliometric analysis focuses on the general idea of a super grid without any constraints, and then the sub-Saharan African context is integrated. The content analysis follows, with the focus on super grids in the sub-Saharan African context.

\subsection{Methodology: Bibliometric analysis}

For this paper, the applicability of super grids to the sub-Saharan African context is investigated; therefore, the literature on super grids is analysed in order to address the question of their applicability to the subSaharan African context. Thus, a bibliometric analysis was conducted to investigate the structure of the scientific literature on super grids. The bibliometric analysis will help to identify the authors that have done the most research on the topic, the institutions that have produced the most documents on the topic, the keywords that are most often used by the authors whose work is most often cited [5]. Furthermore, to understand the concept of super grids, a keyword analysis was done to investigate what other concepts are similar to a super grid. This bibliometric analysis was based on Chapin and Ligtvoet [6], who conducted a keyword analysis by starting with the base keywords and then listing the additional keywords related to the base keywords. The keywords used for the bibliometric analysis are listed in Table 1.

Table 1: Keywords

\begin{tabular}{|l|l|}
\hline Keyword & Additional keywords \\
\hline Super grid & Mega grid, supersmart grid, superior grid, power pools, synchronous grid, interconnected grid \\
\hline
\end{tabular}

Using the keywords in Table 1, Scopus was searched for relevant documents. Based on those search results, the most frequently used keywords - other than the base and additional keywords - were listed (Table 2). This was done to verify whether any keywords were missed when the additional keywords in Table 1 were chosen. The 'interconnected power grid' keyword from Table 2 was added to the list of keywords in Table 1. The new list of keywords can be seen in the left-hand column of Scopus search phrases in Table 3. This keyword was important to add because it is additional to the 'interconnected grid' keyword. Last, the list of the most frequent keywords shown there had a strong focus on renewable energy and sustainability.

Table 2: The most frequently used keywords (other than the chosen base and additional keywords)

\begin{tabular}{|l|l|}
\hline Keywords & \\
\hline Electric power systems & Power markets \\
\hline Electrical power transmission networks & Energy management \\
\hline Electric power system interconnection & Renewable energy \\
\hline Electric utilities & Hydro electricity \\
\hline Electric power transmission & Solar energy \\
\hline Wind power & Sustainable development \\
\hline Commerce & Climate change \\
\hline Renewable energy resources & Interconnected power grid \\
\hline
\end{tabular}

For this paper, the focus on the sub-Saharan African context was important in order to investigate what research had already been done in the field of super grids, and to assess how it could be of value when deciding whether a super grid was applicable to this context. For the bibliometric analysis of the subSaharan African context, sub-Saharan Africa was added to the Scopus search along with each country in sub-Saharan Africa, as seen in Table 3. When the frequently used keywords were investigated, the sub- 
Saharan African context showed that there was an even stronger focus on renewable energy and sustainability.

Table 3: Scopus search phrases

\begin{tabular}{|c|c|}
\hline Super grids & Sub-Saharan Africa + Super grids \\
\hline $\begin{array}{l}\text { TITLE-ABS-KEY(("super grid") OR ("Mega } \\
\text { grid") OR ("supersmart grid") OR } \\
\text { ("superior grid") OR ("power pools") OR } \\
\text { ("synchronous grid") OR } \\
\text { ("interconnected grid") OR } \\
\text { ("interconnected power grid")) }\end{array}$ & $\begin{array}{l}\text { TITLE-ABS-KEY(("super grid") OR ("Mega grid") OR ("supersmart grid") OR } \\
\text { ("superior grid") OR ("power pools") OR ("synchronous grid") OR } \\
\text { ("interconnected grid") OR ("interconnected power grid")) AND (TITLE- } \\
\text { ABS-KEY(("Sub Saharan Africa") OR ("Angola") OR (" Benin") OR } \\
\text { ("Botswana") OR ("Burkina Faso") OR ("Burundi") OR ("Cape Verde") OR } \\
\text { ("Cameroon") OR ("Central African Republic") OR ("Chad") OR ("Comoros") } \\
\text { OR ("Democratic Republic of the Congo") OR ("Republic of the Congo") OR } \\
\text { ("Cote d'Ivoire") OR ("Djibouti") OR ("Equatorial Guinea") OR ("Eritrea") OR } \\
\text { ("Ethiopia") OR ("Gabon") OR ("Gambia") OR ("Ghana") OR ("Guinea") OR } \\
\text { ("Guinea-Bissau") OR ("Kenya") OR ("Lesotho") OR ("Liberia") OR } \\
\text { ("Madagascar")OR ("Malawi") OR ("Mali") OR ("Mauritius") OR } \\
\text { ("Mozambique") OR ("Namibia") OR ("Niger") OR ("Nigeria")OR ("Rwanda") } \\
\text { OR ("Sao Tome and Principe") OR ("Senegal") OR ("Seychelles") OR ("Sierra } \\
\text { Leone") OR ("Somalia") OR ("South Africa") OR ("South Sudan") OR } \\
\text { ("Sudan") OR ("Swaziland" )OR ("Tanzania") OR ("Togo") OR ("Uganda") OR } \\
\text { ("Zambia") OR ("Zimbabwe"))) }\end{array}$ \\
\hline
\end{tabular}

\subsection{Methodology: Content analysis}

According to Bryman and Bell [7], a content analysis is "an approach to the analysis of documents and text (which may be printed or visual) that seeks to quantify content in terms of predetermined categories, and in a systematic and replicable manner". The themes of the document are then discussed by researchers with a predominant interest in this field of study [7]. These themes can be analysed and studied to see what the context is and to answer questions about the roles and strengths of the particular theme [7]. The content analysis method can be used for either qualitative or quantitative data. It can also be used in an inductive or deductive way [8]. This research is qualitative, and is analysed inductively. Qualitative content analysis is a controlled, empirical methodology that offers in-depth insights into an area of research that was hitherto not understood well [9].

Figure 1 shows how the content analysis is performed. First, the research questions are formulated and written down. This will show what the content analysis must answer. Second, the criteria must be formulated about the articles to be analysed and those that should be ignored. After that, the best articles are chosen according to the criteria set for these purposes. Then the articles are analysed, and the themes, ideas, and concepts are coded in Atlas.ti. After that, the important themes, ideas, and concepts that are similar are grouped and then categorised. When between 10 and 50 per cent of the articles have been analysed, the content may show that the criteria should change, or that other research questions must be added, removed, or updated. Then the model starts again at step 1 or step 2 . When there are no problems with the criteria or research questions, all the articles can be worked through and categorised. When all the articles have been worked through, the important themes should have been addressed. The key findings are summarised, and then the results are explained and interpreted.

When the methodology of section 2.1 was implemented, the search results for the keywords were listed (Table 4). These statistics were drawn up using the search results of Scopus during June 2021. The literature search for super grids resulted in 186 documents; and when the additional keywords were included, the total number of documents increased to 10451 . The total citations numbered 14895 with the additional keywords; the year in which most of the articles were published was 2019, which futher demonstrates the currency of the topic of super grids.

Table 4: Scopus results

\begin{tabular}{|l|l|l|l|l|}
\hline $\begin{array}{l}\text { Search } \\
\text { term }\end{array}$ & $\begin{array}{l}\text { Total of documents for } \\
\text { search term }\end{array}$ & $\begin{array}{l}\text { Additional } \\
\text { keywords }\end{array}$ & $\begin{array}{l}\text { Total } \\
\text { citations }\end{array}$ & $\begin{array}{l}\text { Year with most documents } \\
\text { written }\end{array}$ \\
\hline Super grid & 186 & 1956 & 19848 & 2019 \\
\hline
\end{tabular}




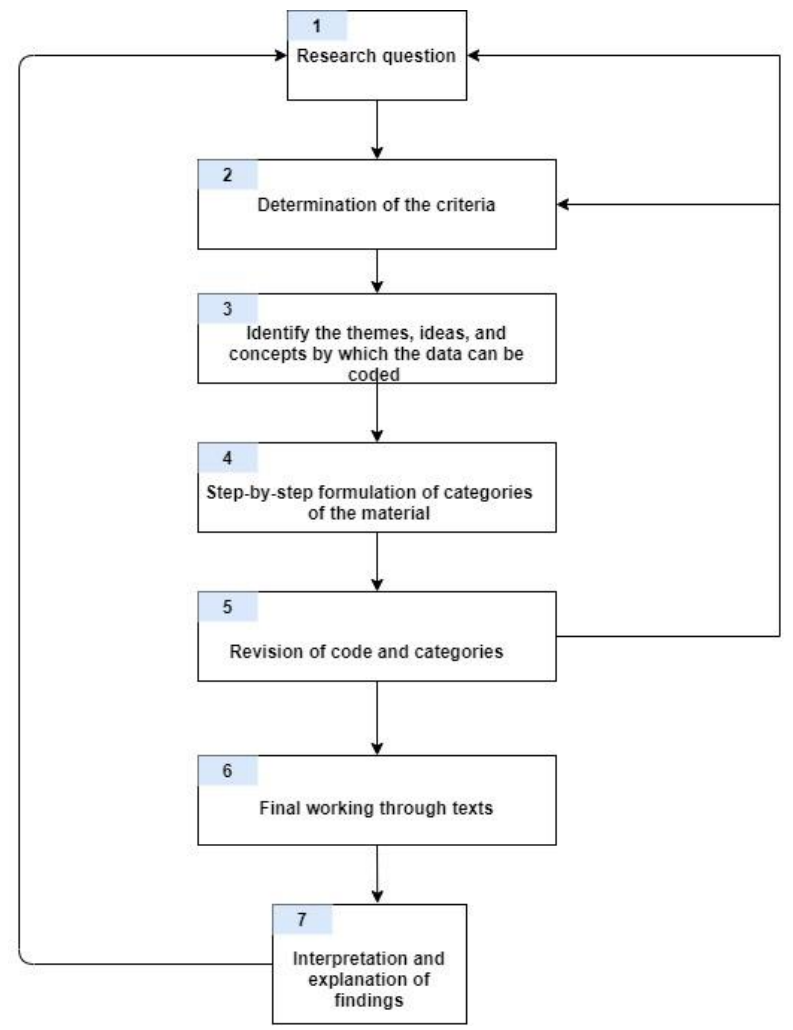

Figure 1: Step-by-step model for qualitative research, adapted from Mayring [9].

Figure 2 shows the years with the number of documents published in each year. There was no time restriction on the articles because the length of the time from when the first person wrote about the topic to the present will give insides on when the topic was introduced and when research in this field increased. The first document was published in 1951; the number of documents increased in 1977, and then reached a low point in 1995; then the documents increased exponentially to a peak in 2019. The countries with the most documents published are China (640), the United States of America (370), India (73), Germany (67), Canada (49), and South Africa (46). The top affiliations were China Electric Power Research Institute, State Grid Corporation of China, North China Electric Power University, Tsinghua University, and South China University of Technology.

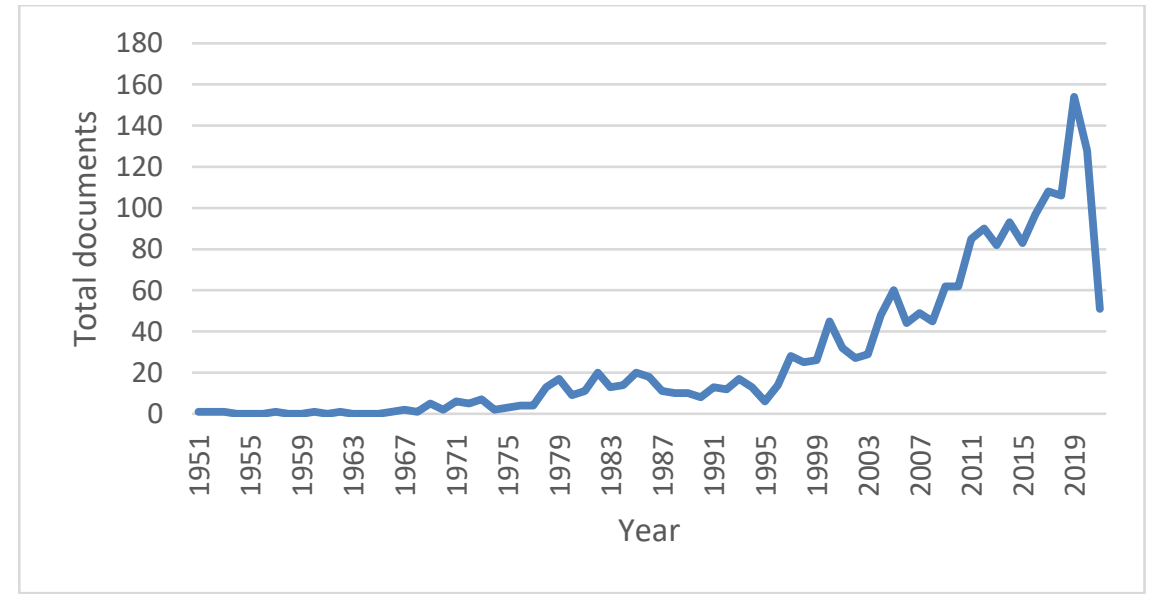

Figure 2: Total number of documents per year, 1951-2019

China dominates the total number of documents because of the vast number of documents emanating from that country. In fact, the top five affiliations are all from China. China's first document was published in 1994, and from 2008 onwards the numbers increased dramatically. The United States of America is also one 
of the leaders in the field, having published their first document in 1951. South Africa started publishing documents in 1994; there were peaks in the number published between 2003 and 2009 and between 2015 and 2019.

The top authors and the number of publications by each author are: M. G. Lauby (17), T. Yu (15), T. J. Hammons (14), H.H. Happ (12), P. Naidoo (12), and Y. Tang (12). Two or more of these researchers have energy, mathematics, economics, decision science, and engineering in common. This is very relevant to the super grid concept, which consists of all five of these research areas. The key focus of each of these authors and institutions is outlined below:

- Mark G. Lauby from the North America Electric Reliability Corporation (NERC) in Atlanta, US. His key subject areas are energy, engineering, economics, and computer science.

- $\quad$ Prof. Toa Yu from the South China University of Technology. His key subject areas are engineering, energy, environmental science, decision science, and mathematics.

- Prof. Thomas James Hammons from the University of Glasgow. His key subject areas are engineering, energy, mathematics, computer science, decision science, and a multidisciplinary focus.

- Harvey H. Happ from the General Electric Company in Boston, US. His key subject areas are energy, mathematics, decision science, social science, materials science and computer science.

- Prof. Pathmanathan Naidoo from Eskom, Johannesburg. His key subject areas are engineering, energy, mathematics, economics, econometrics, and finance.

- Yong Tang from Chinas Electric Power Research Institute in Beijing, China. His key subject areas are engineering, energy, mathematic, social science, physics and astronomy and material science.

Furthermore, a bibliometric analysis was done for the sub-Saharan African context with Scopus. This resulted in a total of 74 documents, as listed in Table 5, with document peaks in 2017 and 2020. The leading countries for the number of documents published are the US (18), South Africa (16), the United Kingdom (7), Nigeria (6), and Zimbabwe (6). The top affiliations are Eskom, Southern African Power Pool, University of Cape Town, and World Bank (US). The top authors are P. Naidoo from Eskom, Johannesburg, and Lawrence M. Musaba from Southern African Power Pool, Harare.

The US publishes the most documents for the sub-Saharan countries. This shows that the US has a great interest in super grids in sub-Saharan Africa. South Africa has the most published documents for a subSaharan African country, and the top affiliations are also from South Africa. This is understandable, because South Africa has the most advanced energy generation in sub-Saharan Africa.

Table 5: Sub-Saharan Africa

\begin{tabular}{|l|l|l|l|}
\hline $\begin{array}{l}\text { Search } \\
\text { term }\end{array}$ & $\begin{array}{l}\text { Total number of documents for search term and } \\
\text { additional terms }\end{array}$ & $\begin{array}{l}\text { Total } \\
\text { citations }\end{array}$ & $\begin{array}{l}\text { Years with most } \\
\text { documents }\end{array}$ \\
\hline Super grid & 74 & 1129 & 2017,2020 \\
\hline
\end{tabular}

\section{CONTENT ANALYSIS}

Super grids play an important role around the world with their interconnection and information management systems, their contributions to the increasingly effective and efficient management of energy, and their potential to be instrumental in realising increasingly sustainable energy systems. In energy-poor sub-Saharan Africa the applicability of such a system is still very uncertain. Therefore, for the first step of the content analysis, the research questions are formulated to address the uncertainty about a super grid in sub-Saharan Africa. The research questions are:

1. Where is the super grid concept implemented in sub-Saharan Africa, if at all?

2. How does the super grid concept work in sub-Saharan Africa?

3. What shortcomings/challenges does the system have?

4. What are the opportunities/advantages the system brings?

5. What is the future potential of this system?

6. How did the systems change through the years of technological progress in sub-Saharan Africa?

Research questions 1 and 2 will give insight into the working of a super grid in different parts of the subSaharan African region. By answering these questions, the scale and the working of the super grid for each region should become clear. With research questions 3,4, and 5, the applicability of the sub-Saharan African context can be evaluated to see whether the super grid concept brings more benefits than challenges. Last, 
for research question 6, the development of super grids in sub-Saharan Africa through the years can be evaluated to see how this concept has evolved.

For the second step, the most important criterion is that the analysis must be for the sub-Saharan African context. For this criterion, a content analysis was done, resulting in 74 documents. The abstracts were then read, and the documents were filtered using the following criteria:

1. Strong focus on trade of energy between different countries. Typically, two or more countries.

2. Focus on the infrastructure for generation and transmission of electricity in sub-Saharan Africa over large areas.

3. Focus on case studies to show what projects have already been executed.

After this, 25 documents were left, and all of them were carefully scrutinised and analysed with Atlas.ti. In step 3, the following themes stood out in the content analysis: trade, interconnections, power pools, renewable energy, utilities, generation, markets, future potential, problems, challenges, opportunities, benefits, and countries of implementation. A word cloud was also conducted in Atlas.ti, with the results shown in Figure 3.

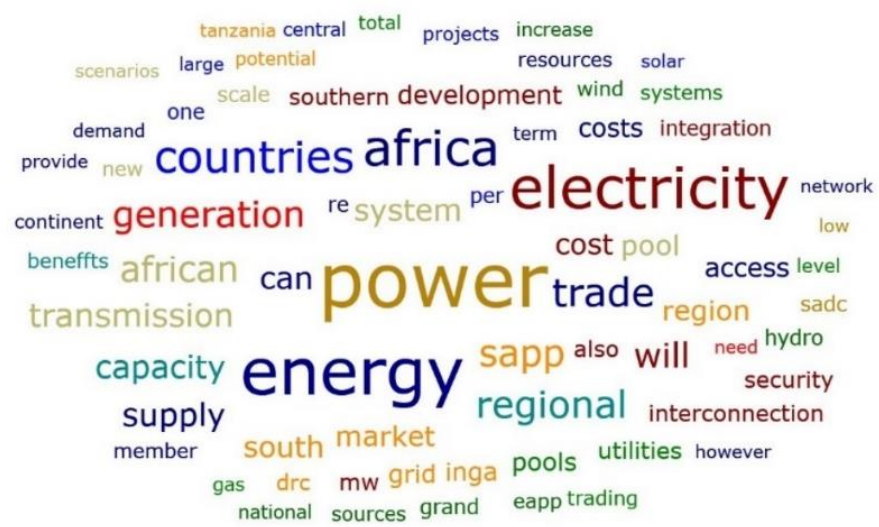

Figure 3: Word cloud of analysed documents

In the 4th step, the themes are categorised into four categories, which can be seen in Table 6 . The reason for using 'positives' and 'negatives' as categories is that six of the themes point directly to either a positive or a negative aspect of a super grid. The 'infrastructure' category was used to categorise the themes that form part of the infrastructure of a super grid. The 'operation' category was created to gather together all the operation themes of a super grid. The reason that 'countries of implementation' was added was to see which countries are already in operation. The themes with their categorisations are shown in Table 6.

Table 6: Categorisation of themes

\begin{tabular}{|l|l|l|}
\hline Category & Theme \\
\hline Positives & Opportunities & Future potential \\
\cline { 2 - 3 } & Benefit & \\
\hline \multirow{2}{*}{ Negatives } & Challenges & Problems \\
\cline { 2 - 3 } & Obstacles & \\
\hline \multirow{2}{*}{ Infrastructure } & Renewable energy & Interconnections \\
\cline { 2 - 3 } & Generation & Utilities \\
\hline \multirow{2}{*}{ Operations } & Trade & Power pools \\
\cline { 2 - 3 } & Markets & Countries of implementation \\
\hline
\end{tabular}

For steps 5 and 6, the document was read through, and the research questions, criteria, themes, and categories of the research were updated. Last, in step 7, the key findings and their implementation are discussed in sections 4.1 and 4.2 respectively.

\subsection{Key findings}

When the documents were read through, it was evident that energy poverty is a big problem in sub-Saharan Africa; but the documents also show that, although there is great energy poverty, sub-Saharan Africa is also the region with the most abundant energy resources in the world. The problem here is that those 
abundant resources are not distributed evenly around the region. An example of this is that most of the coal (96\%) is produced in South Africa [10], 75 per cent of the liquid fuels are produced in Angola and Nigeria [11], and hydro plants are mostly constructed on the Congo, Nile, Niger, Volta, and Zambezi Rivers [10]. Europe faced a similar problem after the 1970s oil crisis, when countries were forced to move away from oil-fired energy generation [12]. France started changing its energy mix and built 13 nuclear power plants in two years [12]. The northern part of Europe started focusing more on hydropower, and the United Kingdom developed gas-fired power plants [12]. With all these different resources, Europe also realised that it must focus more on transnational connections, resulting in all European countries (except for Iceland and Cyprus) being interconnected by the end of the 20th century [12]. There is a need in sub-Saharan Africa to use these rich resources and to distribute them to the countries that do not have access to natural energy resources. One of the options to achieve this would be to develop a super grid that, with its interconnections and energy pooling, would help with the regulated and controlled trade and exchange of these resources to countries in sub-Saharan Africa in order to stimulate economic development in this region.

Power pools ensure that the utilities in different countries work together, thus minimising the cost and increasing the reliability of the system. A correctly implemented power pool could result in a successful super grid for sub-Saharan Africa. The first creation of a regional power pool in Southern Africa took place In 1995 [13]. This was the Southern African Power Pool, which is still the most advanced power pool in subSaharan Africa. Two main influences led to the creation of the pool. First, in 1992, there was a severe drought in Southern Africa that impacted the generation yield of the hydropower producers of Zambia, Malawi, and Zimbabwe [14]. This energy problem highlighted the need for these countries to work together with thermal-rich South Africa, which at the time was generating a surplus amount of energy, and also with the hydro-rich countries of the northern hemisphere. The need for trade also drove South Africa to create a regional pool, because that country could earn income from selling its surplus energy [14]. The secondlargest influence was the fall of apartheid in the early 1990s. South Africa wanted to restore its relationship with other countries; and so, to do this, it helped them with their energy shortages [14]. South Africa, therefore, played a critical role in creating the power pool, and was the primary economic force that drove the power pool. It still exercises this leadership role today [14].

After the Southern African Power Pool, another three power pools were created in sub-Saharan Africa. The idea of a Western African Power Pool originated in 1999; it was finally established in 2001 by the heads of the relevant states [15]. After the success of the Western African and Southern African power pools, the Union of African Power helped Central and Eastern Africa to create their power pools with the Central African Power Pool in 2003 and the Eastern African Power Pool in 2005 [15]. These two power pools are still in their beginning phases compared with the other two. In this content analysis, there was a strong focus on power pools; and this will be the way in which sub-Saharan Africa must start implementing its super grid. The countries affiliated with each power pool are shown in the appendix. The Democratic Republic of the Congo falls in two of three three power pools (it is not part of the Western Africa Power Pool), as seen in the Appendix.

The Southern African Power Pool has successfully operated as a stand-alone power pool, and is now moving to a tighter pool in which competition can increase and members can sell their electricity and make a profit [16]. In 2001, the Southern African Power Pool started with the short-term energy market, which was the first step in developing a regional energy market through which competitive trade could be established. With a short-term energy market, energy is traded a day in advance, but bilateral contracts still get preference over short-term energy market contracts for trade over the transmission lines [17]. The shortterm energy market is designed to make trade look as though it happens in real time [17]. For the energy market, the currency of trade is the United States dollar or the South African Rand [17]. In 2004 the Southern African Power Pool finally developed a competitive energy market (a day-ahead market) in which members can bid for the next day. This market enabled hourly energy contracts for the next day [14]. In 2016 an intra-day market was developed that made it possible to trade one hour before delivering [14]. This enables utilities to adapt their purchases if they still need some volume after the day-ahead market biddings [14].

In the Eastern Africa Power Pool there has been only a small amount of trade through the years. It is thus important for this power pool to look at other strategies to increase trade while reducing $\mathrm{CO}_{2}$ emissions. According to Remy and Chattopadhyay [18], if the Eastern Africa Power Pool were to move from 'business as usual' to a shallow integration, it could gain $\$ 7.6$ billion in trade where existing and committed transmission lines are used. With tight integration, 18.6 billion dollars in trade could be gained, and also a 30 per cent reduction in $\mathrm{CO}_{2}$. Moving from shallow to tight integration new interconnection needs to be added with tighter coordination of generation plans [18]. 
There are also challenges that the countries of sub-Saharan Africa face in respect of trade. Some subSaharan African countries are involved in multiple regional integration schemes, with most of them having different agendas [16]. This causes problems between trade agreements because of differences in the power pools' technical standards, and differences in how they regulate and in the methods they use for trade [16]. A challenge that limits trade is when a utility does not have the financial capacity to pay for energy imports; this limits their ability to import extra electricity to meet the demand. Europe faces similar challenges in building a super grid because of strict regulations in the energy sector. One of the biggest obstacles in the process of building a super grid is the continual negotiations because of differences in policies and rules around Europe [19]. What distinguishes Europe from sub-Saharan Africa is its financial situation. Europe has 11 of the 25 top countries in respect of GDP, whereas sub-Saharan Africa has only Nigeria in the top 25 [20].

But trade also brings a lot of benefits and opportunities. One of the benefits is that it makes electricity more affordable and improves the reliability of supply through economies of scale. This is done when resources are more diversified, making it less destructive if some resources have disruptions such as drought. Trade also makes it possible for countries to import electricity, as that is cheaper than building expensive generation facilities to counteract their lack of resources.

Through the content analysis, a specific infrastructure project was identified for the purposes of describing a super grid: the Inga Dam project, the world's largest hydroelectricity plant, which is being built in the Democratic Republic of the Congo. This project will cost $\$ 80$ billion and will generate $44000 \mathrm{MW}$. The energy thus generated will be transmitted via interconnections to the four regional power pools in sub-Saharan Africa [21]. With this project, half of the $\$ 80$ billion cost will go to transmission extension and upgrades [21]. The three main interconnection projects are the Northern Highway from Inga to Sudan, Chad, and Egypt, and is $5300 \mathrm{~km}$ in length; then there is the Southern Highway, which runs from Inga to Angola, Namibia, Botswana, and then South Africa, and is $2734 \mathrm{~km}$ in length; and the third is the Western Highway, which runs from Inga to Congo, Gabon, Cameroon, and then Nigeria, and is $1400 \mathrm{~km}$ in length [21]. South Africa is the largest purchaser with 2500MW of energy from the Inga dam [21]. This project will bring great opportunities to the region because of its scale, and it will provide thousands of jobs, increase sub-Saharan Africa's energy generation capacity significantly, and also bring in foreign investment [21]. The challenge that this big project will raise is that it could lead to corruption and the misuse of funds because of its financial scale.

Sub-Saharan African is relatively underdeveloped in respect of wind and solar energy. In the Eastern Africa Power Pool, Kenya leads in terms of installed capacity, with 14 per cent of its total capacity comprising wind and solar [22]. Offshore wind also holds great potential for the Southern African Power Pool, with the coastal region having more than half the continent's potential. This could diversify the energy potential, and help the region to meet the United Nations' goal of affordable, reliable, sustainable, and modern energy for all [2]. The Southern African Power Pool also has the Southern African Renewable Energy Independent Power Producer Procurement Programme (REIPPP). With nine projects amounting to 417.1MW solar and 562.5MW wind power, REIPPPP aimes to generate 3725MW of renewables by the end of 2030 [15].

Interconnection is not a new thing for sub-Saharan Africa. The DRC and Zambia started cross-border trading in 1950 with a $1700 \mathrm{~km}$ 220kV line; Uganda traded with Kenya using a $132 \mathrm{kV}$ line in 1955; Zambia was connected to Zimbabwe by a $2 \times 330 \mathrm{kV}$ interconnection in the 1960s; and Mozambique was connected to South Africa with a 533kV high-voltage direct-current line of $1400 \mathrm{~km}$ in 1975 [15]. According to the Program for Infrastructure Development in Africa, the predicted energy demand will grow from 590TWh to 3100TWh by 2040 [15]. This means that there must be a large increase in transmission line capacity. With a power pool that is trying hard to increase trade, the level of cross-border interconnection is still far too low: the Central Africa Power Pool is at 0.2 per cent, the Eastern Africa Power Pool at 0.4 per cent, the Western Africa Power Pool at 6.9 per cent, and the Southern African Power Pool at 7.5 per cent [23]. This means that $\$ 5.4$ billion must be invested each year in transmission lines in the region [15].

To create a super grid, all of the regional power pools must work together and share their cheaper energy sources, create competitiveness, and attract investors. By joining all of the regional power pools together, sub-Saharan Africa could compete with large developing countries such as China, India, and Brazil, and could even exceed them in generation potential and economies of scale [24]. This would also help to ensure that not just some sub-Saharan African countries or regions would benefit, but that all of them would benefit from economies of scale [24]. 


\subsection{Discussion}

After the content analysis had been conducted, it became clear from the key findings in section 4.1 that the super grid concept involving a large geographical area in which countries are interconnected was already being implemented in sub-Saharan Africa. This super grid principle operates in the form of power pools that enable energy to be traded between the countries in the region and to develop their frameworks and policies. The research also showed that the most advanced power pool in respect of trade and interconnection is the Southern African Power Pool. The research also showed that Africa has great potential for diverse forms of energy, but those countries in sub-Saharan Africa focus mostly on hydro energy for new power stations. This is problematic because, if most of the energy is generated from hydro, the risks of blackouts and loadshedding are great owing to the likelihood of droughts - and that, of course, would cause the power plants to operate below their potential. It was also seen that the power pools focus more on the easy part of the energy problem - i.e., the generation of energy - and a lot less on the regulated and controlled transmission and distribution of energy in accordance with real-time demand and supply curves. Power pools handles the issue the wrong way around, and could cause great problems in the future because, if enough energy were to be generated but not distributed to the locations of net demand, in line with the principles of a super grid, then it would be worthless.

Africa has significant potential to be an energy-rich region; but, because of corruption, the lack of knowledge, and the lack of cooperation between countries, the vision of working towards a net energy reserve for the wider sub-Saharan region would come to nothing. Therefore, a super grid would be relevant because, if it were implemented well, economic growth in the region would increase. The answer to the problem thus lies in co-operation between nations and in a focus on building and maintaining the interconnections between them. By working together, sub-Saharan Africa could set the standard for an economy of scale in respect of energy generation and real-time distribution and utilisation.

\section{CONCLUSION}

In this paper the super grid concept was analysed. First, bibliometric analyses were conducted through which the super grid phrase was analysed. This was expanded with additional keywords to prevent the loss of important insights. The results showed that 1956 documents were found in Scopus. It was clear that China has dominated the research in terms of numbers and affiliation. The bibliometric analysis was expanded further to see what research had been done for the sub-Saharan African context. It resulted in 74 articles, with N. Naidoo and M. Musaba emerging as the main researchers. After the bibliometric analysis, a content analysis was conducted to see whether there were any parallels between super grids and the subSaharan African context. The content analysis showed that the super grid concept has been implemented in sub-Saharan Africa using the power pool concept, through which energy is traded between the nations of the region. The research also showed that there is great potential for a super grid in sub-Saharan Africa because of the rich energy resources that are not evenly distributed throughout the region. With crossborder interconnections, this problem could be addressed relatively quickly. The super grid would also have a great impact on the environment, because it would promote renewable energy by overcoming the problem of its intermittency. By increasing the generation of renewable energy and adapting the integration of power pools, greenhouse gases would be drastically reduced. The research showed that, although there is a cross-border interconnection in sub-Saharan Africa, its scale and efficiency have not yet been fully developed. Therefore, a super grid could play an enormous role in reducing energy poverty. But it would be important for the right policies to be implemented and for countries to work together to create an economy of scale.

It is more difficult to build a working super grid in sub-Saharan Africa than it is in other regions, such as Europe and North America. Therefore, it is recommended that future research look at whether the challenges of a super grid could be mitigated by Industry 4.0 technology. It is also recommended that future research be done to identify the technology maturity level in each country in sub-Saharan Africa, and how this might play a role in achieving a better working super grid.

\section{REFERENCES}

[1] A. Belke, F. Dobnik, and C. Dreger, “Energy consumption and economic growth: New insights into the cointegration relationship,” Energy Econ., vol. 33, no. 5, pp. 782-789, 2011.

[2] P. Elsner, "Continental-scale assessment of the African offshore wind energy potential: Spatial analysis of an underappreciated renewable energy resource," Renew. Sustain. Energy Rev., vol. 104, pp. 394-407, 2019.

[3] R. Itiki, M. Manjrekar, and S. G. di Santo, "Comparative evaluation of super grid topologies proposed for Europe and Latin America," in 2019 North American Power Symposium(NAPS), 2019, pp. 1-6. 
[4] African Centre for Economic Transformation, "Energy crisis: Africa won't grow without efficient power - Aliko Dangote," 2017. https://acetforafrica.org/media/energy-crisis-africa-wont-grow-without-efficient-power-alikodangote/ (accessed Apr. 13, 2021).

[5] T. U. Daim, G. Rueda, H. Martin, and P. Gerdsri, "Forecasting emerging technologies: Use of bibliometrics and patent analysis," Technol. Forecast. Soc. Change, vol. 73, no. 8, pp. 981-1012, 2006.

[6] E. J. L. Chappin and A. Ligtvoet, "Transition and transformation: A bibliometric analysis of two scientific networks researching socio-technical change," Renew. Sustain. Energy Rev., vol. 30, pp. 715-723, 2014.

[7] A. Bryman and E. Bell, Research methodology: Business and management contexts, 3rd ed., Oxford University Press South Africa, 2014.

[8] P. O. Pineau, "Electricity sector integration in West Africa," Energy Policy, vol. 36, no. 1, pp. 210-223, 2008.

[9] S. Elo and H. Kyngäs, "The qualitative content analysis process," J. Adv. Nurs., vol. 62, no. 1, pp. 107-115, 2008.

[10] P. Mayring, "Qualitative content analysis," FORUM Qual. Soc. Res. Sozialforsch., vol. 1, no. 2, pp. 159-176, 2004, http://nbn-resolving.de/urn:nbn:de:0114-fqs0002204.

[11] W. J. Lee, "Technical issues: Area control considerations in the WAPP and SAPP areas," 2005 IEEE Power Eng. Soc. Gen. Meet., vol. 2, pp. 1808-1812, 2005.

[12] U.S. Energy Information Administration, “Oil and natural gas in sub-Saharan Africa,” pp. 1-25, 2013. [Online]. Available: https://ecdpm.org/publications/african-power-pools-regional-energy-national-power/ (accessed 23 November 2021)

[13] Z. Liu, Y. Zhang, Y. Wang, N. Wei, and C. Gu, "Development of the interconnected power grid in Europe and suggestions for the energy internet in China," Glob. Energy Interconnect., vol. 3, no. 2, pp. 111-119, 2020.

[14] P. Valickova and N. Elms, "Potential gains from regional integration to reduce costs of electricity supply and access in Southern Africa," Energy Sustain. Dev., vol. 62, pp. 82-100, 2021.

[15] A. Medinilla, B. Byiers, and K. Karaki, "African power pools regional energy, national power," Discuss. Pap., no. 244, pp. 1-30, 2019, [Online]. Available: www.ecdpm.org/dp244/(accessed Jun. 21, 2021).

[16] C. Kambanda, "The African experience," In International Tradein Sustainable Electricity: Regulatory Challenges in International Economic Law. Cambridge: Cambridge University Press, 2017.

[17] L. Bingandadi, "Growing pains; Southern African power pool-governance and institutional development issues and challenges," no. July, pp. 11-15, 2005.

[18] L. Musaba, "The development of the SAPP competitive electricity market," Proc. Inaug. IEEE PES 2005 Conf. Expo. Africa, vol. 2005, no. July, pp. 188-194, 2005.

[19] T. Remy and D. Chattopadhyay, "Promoting better economics, renewables and $\mathrm{CO}_{2}$ reduction through trade: $\mathrm{A}$ case study for the Eastern Africa power pool," Energy Sustain. Dev., vol. 57, pp. 81-97, 2020.

[20] B. Gardiner, “An energy supergrid for Europe faces big obstacles,” London, Jan 16, 2012 [Online]. Available: https://www.nytimes.com/2012/01/17/business/global/17iht-rbog-grid17.html.

[21] C. Silver, "The top 25 economies in the world," 2020, [Online]. Available: https://www.investopedia.com/insights/worlds-top-economies/ (accessed Aug. 25, 2020).

[22] N. Green, B. K. Sovacool, and K. Hancock, "Grand designs: Assessing the African energy security implications of the Grand Inga Dam,” Afr. Stud. Rev., vol. 58, no. 1, pp. 133-158, 2015.

[23] R. Konidena, V. Bhandari, and A. Mburu, "Best practices from international experiences for eastern Africa countries regarding ancillary services markets," Electr. J., vol. 33, no. 7, p. 106800, 2020.

[24] The Infrastructure Consortium for Africa, "Regional power status in African power pools report," 2016, [Online]. Available:https: //www.icafrica.org/en/knowledge-hub/article/regional-power-status-in-africa-power-pools2016-update-330/ (accessed June. 21, 2021).

[25] P. Naidoo and L. Musaba, "Fundamental elements for the forward planning of the 'Cape to Cairo' interconnected power system," 2007 IEEE Power Eng. Soc. Gen. Meet. PES, pp. 7-9, 2007. 
APPENDIX

Table 7: Table of countries in each power pool

\begin{tabular}{|l|l|l|l|}
\hline List of countries for SAP & $\begin{array}{l}\text { List of countries for } \\
\text { WAP }\end{array}$ & List of countries for EAP & List of countries for CAP \\
\hline Angola & Benin & Burundi & Angola \\
\hline Botswana & Burkina Faso & $\begin{array}{l}\text { Democratic Republic of the } \\
\text { Congo }\end{array}$ & Burundi \\
\hline $\begin{array}{l}\text { Democratic Republic of the } \\
\text { Congo }\end{array}$ & Cape Verde & Djibouti & Cameroon \\
\hline Eswatini & Côte d'Ivoire & Egypt & Republic of Congo \\
\hline Lesotho & The Gambia & Ethiopia & Central Africa Republic \\
\hline Mozambique & Ghana & Kenya & Chad \\
\hline Malawi & Guinea & Libya & $\begin{array}{l}\text { Democratic Republic of the } \\
\text { Congo }\end{array}$ \\
\hline Namibia & Guinea-Bissau & Rwanda & Gabon \\
\hline South Africa & Liberia & Sudan & Equatorial Guinea \\
\hline Tanzania & Mali & South Sudan & São Tomé and Príncipe \\
\hline Zambia & Nigeria & Tanzania & \\
\hline Zimbabwe & Senegal & Uganda & \\
\hline & Sierra Leone & & \\
\hline & Togo & & \\
\hline
\end{tabular}

